\title{
KINERJA GURU BIMBINGAN KONSELING DI KOTA KUPANG MENURUT PERSEPSI KEPALA SEKOLAH
}

\author{
Dhiu Margaretha $\left(^{1}\right)^{1)}$, Maria Erlinda $\mathbb{i}^{2)}$, dan Yohanes Demon Doni $\mathbb{B}^{3)}$ \\ ${ }^{1,2,3}$ Bimbingan Konseling, Universitas Katolik Widya Mandira \\ 1,2,3 J1. Jend. Ahmad Yani 50-52 Kupang, 85225 \\ E-mail : margarethadhiu@unwira.ac.id ${ }^{1)}$, mariaerlinda54@unwira.ac.id ${ }^{2)}$,dan johndemon@unwira.ac.id ${ }^{3)}$
}

\begin{abstract}
ABSTRAK
Kinerja guru bimbingan konseling adalah bentuk hasil kerja yang dicapainya dalam melaksanakan penugasan yang dibebankan kepadanya, baik secara kualitas maupun kuantitas, yang dilaksanakan selama periode waktu tertentu. Penelitian ini bertujuan untuk mengetahui kinerja guru Bimbingan Konseling (BK) menurut persepsi kepala sekolah sebagai pemimpin, manajer, dan supervisor terhadap semua kegiatan yang dilaksanakan oleh warga sekolah sesuai dengan tugas dan tanggung jawab yang diembannya. Desain penelitian yang digunakan adalah pendekatan kuantitatif dengan jenis survey. Penentuan sampel menggunakan teknik simple random sampling dengan jumlah sampel sebanyak 65 orang kepala sekolah pada Sekolah Menengah Pertama (SMP), Sekolah Menengah Atas (SMA), dan Sekolah Menengah Kejuruan (SMK) di Kota Kupang. Data dikumpulkan dengan menggunakan instrumen kuesioner, dan dianalisis dengan menggunakan persentase. Hasil penelitian ini adalah kinerja guru bimbingan konseling secara umum tergolong cukup $(55 \%)$. Jika dilihat per-aspeknya, maka kinerja dalam perencanaan dan pengembangan program, cukup (58\%), pelaksanaan layanan-layanan BK, cukup (55\%), serta evaluasi dan tindak lanjut, cukup (63\%). Hal ini menunjukkan bahwa menurut pengetahuan, pemahaman, keyakinan, perasaan, dan tindakan kepala sekolah, kinerja guru bimbingan konseling masih berada pada kategori rata-rata, belum menunjukkan kinerja yang baik. Hambatan yang dialami adalah pada hampir $70 \%$ sekolah tidak ada jam tatap muka dengan siswa, guru BK sering dibebani dengan tugas-tugas lain di luar tugas pokoknya, kurangnya sarana prasarana yang menunjang pelaksanaan tugas seperti tidak ada ruang khusus bimbingan.
\end{abstract}

Kata kunci : Kinerja, Tugas Pokok, Guru BK, Persepsi, Kepala Sekolah

\section{PENDAHULUAN}

Pembinaan guru dan tenaga kependidikan di Indonesia dilakukan dengan cara antara lain menerapkan sistem penilaian kinerja guru yang sahih, andal, transparan, dan berkesinambungan. Guru dikategorikan atas guru mata pelajaran dan guru Bimbingan dan Konseling. Guru mata pelajaran bertugas dalam mata pelajaran tertentu dengan tugas pokok merencanakan pembelajaran, melaksanakan pembelajaran, menilai hasil pembelajaran, membimbing dan melatih peserta didik dan melaksanakan tugas tambahan. Sedangkan Guru BK memiliki tugas, tanggung jawab, wewenang dalam pelaksanaan pelayanan bimbingan dan konseling terhadap peserta didik di Sekolah (Kemensesneg, 2017). Disadari bahwa pendidikan yang hanya melaksanakan bidang instruksional atau pengajaran dengan mengabaikan komponen lain (pengembangan diri), hanya akan menghasilkan peserta didik yang pintar dan terampil dalam aspek akademik, tetapi kurang memiliki kemampuan atau kematangan dalam aspek kepribadian. Berdasarkan kondisi seperti inilah keberadaan BK sebagai aspek pengembangan diri menjadi sangat penting. Untuk itu maka bimbingan dan konseling sebagai salah satu bidang pelayanan yang terintegrasi dalam keseluruhan upaya pendidikan di sekolah perlu menunjukkan tanggung jawab dan kepedulian secara profesional.

Guru BK adalah tenaga ahli atau profesional yang diharapkan dapat memfasilitasi peserta didik untuk mencapai kemandirian dalam berbagai aspek perkembangan yang meliputi aspek pribadi, sosial, akademik dan karier. Untuk mencapai keberhasilan dalam melaksanakan tugasnya sangat dibutuhkan kemampuan guru BK dalam menciptakan kerja sama, penguasaan ilmu dan kompetensi yang diharuskan, serta menunjukkan kinerja yang dapat diandalkan. Kinerja merupakan salah satu faktor penentu sekaligus menjadi tolok ukur keberhasilan penyelenggaraan BK di sekolah. Kinerja tersebut secara tegas dirumuskan sebagai salah satu sub kompetensi konselor yakni menyelenggarakan bimbingan dan konseling yang berguna untuk kemandirian peserta didik.

Kata kinerja merupakan terjemahan dari bahasa Inggris performance, berasal dari kata to perform yang berarti menampilkan atau melaksanakan. Kinerja merujuk pada 2 hal yaitu proses melaksanakan suatu pekerjaan dan hasil yang dicapai (Wibowo, 2019). Sedangkan Bernadin \& Russel (Supardi, 2016) mendefinisikan "Performance is defined as the record of out-comes produced on a specified job function or activity during a specified time period". Artinya kinerja 
merujuk pada hasil-hasil yang diperoleh dari suatu pekerjaan yang spesifik atau aktivitas selama periode waktu tertentu. Jadi kinerja adalah kemampuan yang ditunjukkan oleh seseorang dalam melaksanakan tugas atau pekerjaannya, serta hasil yang dicapai. Kinerja dikatakan baik dan memuaskan apabila hasil yang dicapai sesuai dengan standar yang telah ditetapkan. Kinerja juga diartikan sebagai hasil kerja, unjuk kerja, dan kemajuan yang telah dicapai seseorang dalam pekerjaannya, sama dengan prestasi kerja.

Selanjutnya, Mangkunegara (Sudibyo, 2019), mengartikan kinerja adalah hasil kerja secara kualitas dan kuantitas yang dicapai seseorang dalam melaksanakan tugasnya sesuai dengan tanggung jawab yang diberikan kepadanya. Jika dikaitkan dengan kinerja guru BK, maka ada 3 dimensi utama yang harus dinilai yaitu perencanaan, pelaksanaan, dan evaluasi serta pelaporan dan tindak lanjut layanan BK. Pelaksanaan tugas utama guru BK tersebut tidak dapat dipisahkan dari kemampuan guru BK dalam penguasaan dan penerapan kompetensi nya (Kementerian Pendidikan dan Kebudayaan, 2014).

Penelitian yang dilakukan oleh Sudibyo (Sudibyo, 2019) pada Guru BK yang tergabung dalam MGBK SMP/MTs Kabupaten Pekalongan, menunjukkan bahwa kinerja guru BK dalam perencanaan program BK sangat rendah, dan hanya berdasarkan pada assessment kebutuhan peserta didik. Sedangkan kebutuhan lingkungan tidak diperhatikan dalam penyusunan program BK. Hal ini sejalan dengan penelitian yang dilakukan oleh Ramadani \& Herdi yang menyimpulkan bahwa assessment kebutuhan peserta didik berkaitan dengan karakteristik dan harapannya, serta assessment lingkungan seperti visi, misi, dan tujuan sekolah, harapan orang tua, kondisi dan kemampuan guru BK, sarana dan prasarana pendukung, dan kebijakan kepala sekolah, merupakan hal pokok yang harus diidentifikasi sebelum menyusun program bimbingan. Dengan demikian, program bimbingan dan konseling yang disusun bersifat komprehensif dan dapat menjawab semua kebutuhan (Ramadani, D., 2021).

Berkaitan dengan kinerja guru BK dalam aspek pelaksanaan, hasil penelitian Solikin (Solikin, 2012) di SMP PGRI Gemuh Kabupaten Kendal menunjukkan bahwa persepsi kepala sekolah tentang kinerja guru BK sangat baik dalam arti guru BK sudah melaksanakan layanan sesuai dengan standar layanan, penguasaan materi sangat baik, sikapnya ramah dan bersahabat, serta penanganan masalah yang dialami siswa dilakukan dengan baik. Hal ini berbeda dengan hasil penelitian Bahri (Bahri, 2020) pada SMA, SMK, dan MA di Provinsi Aceh yang menunjukkan bahwa kinerja guru BK pada tahap pelaksanaan masih kurang karena tidak semua layanan BK dilaksanakan, walaupun pada aspek perencanaan sudah cukup baik.

Kinerja guru BK dalam proses pelayanannya, dipengaruhi oleh berbagai faktor, seperti : sumber daya manusia, pengetahuan dan pemahaman terhadap tugas dan tanggung jawab yang diembannya, persepsi yang tepat tentang tugas, komitmen kerja, motivasi kerja, sarana dan prasarana serta berbagai pengaruh lingkungan. Penelitian yang dilakukan oleh Saputri, dkk menjelaskan bahwa kinerja guru BK berada pada kategori kurang (67\%), dan hal ini sebanding dengan upaya pembinaan yang dilakukan oleh kepala sekolah dan pengawas yang ternyata sangat kurang (Saputri, S.M., Prayitno., \& Jaya, 2018). Sedangkan hasil penelitian dari Nagul, dkk (Nagul, W., Yusuf, A.M., 2013) menunjukkan bahwa kinerja guru BK di SMPN se-Kota Kupang tergolong sangat tinggi atau sangat baik.

Untuk aspek evaluasi dan tindak lanjut, hasil penelitian Bahri menunjukkan bahwa banyak guru BK yang tidak melakukan evaluasi karena tidak memiliki kemampuan untuk merancang instrumen penilaian. Akibatnya, berhasil atau tidaknya kegiatan BK dan efektif atau tidaknya pelaksanaan layanan tidak dapat diketahui. Dengan demikian pelaporan dan tindak lanjut tidak dapat dirumuskan (Bahri, 2020).

Salah satu faktor lingkungan yang mempengaruhi kinerja guru BK adalah berkaitan dengan bagaimana peran kepala sekolah sebagai pemimpin (headmaster) dalam menghadapi tugas dan tanggung jawab guru BK di sekolah (Hapsyah, D.R., \& Herdi, 2019). Gaya kepemimpinan kepala sekolah dipandang sebagai salah satu faktor yang berpengaruh terhadap kinerja guru Bimbingan dan Konseling (Siregar, 2018). Jadi dalam hal ini, perilaku yang ditampilkan atau cara yang ditempuh oleh kepala sekolah dalam menjalankan kepemimpinannya berpengaruh pada kinerja guru BK.

Hal ini menunjukkan bahwa kinerja guru BK dipengaruhi oleh faktor dalam diri manusia sendiri (internal) seperti usaha, motivasi, kemampuan, keterampilan, ketepatan persepsi terhadap peran dan tugas, dan faktor dari luar diri (eksternal) seperti kesempatan untuk kinerja, ketersediaan sumber daya yang dibutuhkan, faktor kelompok, organisasi, dan lingkungan kerja (Wibowo, 2018).

Tugas pokok guru BK khusus untuk Sekolah Menengah dipaparkan dalam Peraturan Pemerintah Nomor 19 Tahun 2017. Ditegaskan bahwa tugas guru BK yaitu membantu peserta didik dalam pengembangan kehidupan pribadi, pengembangan kehidupan sosial, pengembangan kehidupan belajar serta pengembangan karier. Bidang pengembangan diri peserta didik tersebut di atas akan dilaksanakan dalam bentuk layanan, yang didukung oleh beberapa kegiatan pendukung layanan (Kemensesneg, 2017).

Sukses tidaknya pelaksanaan tugas pokok dalam bidang BK di sekolah sangat dipengaruhi oleh kemampuan guru BK. Kemampuan guru BK ini terutama berkaitan dengan pengetahuan dan pemahaman mereka terhadap tugas yang dibebankan kepadanya serta persepsi mereka terhadap tugas. Ada indikasi bahwa kegagalan pelaksanaan pelayanan BK di sekolah disebabkan oleh kurangnya pemahaman guru BK terhadap tugas-tugas yang harus dilaksanakannya serta 
persepsi yang keliru terhadap tugas yang menjadi tanggung jawabnya. Selain kemampuan melaksanakan tugas pokoknya guru BK juga perlu mengetahui, memahami serta memiliki persepsi yang tepat terhadap berbagai ketentuan atau peraturan perundang-undangan tentang BK, sebagai dasar atau pedoman dalam menjalankan tugasnya sebagai guru BK di Sekolah.

Di samping persepsi tentang tugas, faktor lain yang turut mempengaruhi kinerja guru BK adalah dukungan lingkungan dan iklim organisasi yang tercipta. Bagi guru BK, tugas dan tanggung jawabnya terlihat pada aktivitas pelayanan BK serta kegiatan administrasi BK yang dikerjakannya akibat dorongan dari dalam diri serta dorongan yang diberikan oleh pihak lain yang terkait dengan pelaksanaan tugas BK di sekolah.

Kondisi riil di lapangan menunjukkan sesungguhnya masih banyak kepala sekolah yang menyatakan bahwa guru BK belum menampilkan kinerja sebagaimana yang diharapkan. Banyak di antara mereka yang menerima tugas lain yang bukan bidang keahliannya. Berdasarkan wawancara dengan beberapa guru BK, terungkap bahwa selama bekerja sebagai guru BK mereka sering dibebankan dengan tugas-tugas lain seperti pembina OSIS, piket, mengawasi dan memberi hukuman kepada siswa yang melakukan pelanggaran disiplin sekolah, dan tidak ada jam BK untuk bimbingan klasikal. Sering juga terjadi ekspektasi yang keliru tentang tugas pokok dan fungsi guru BK dari guru mata pelajaran, wali kelas, maupun pimpinan sekolah. Hal ini menyebabkan mereka dibebankan dengan berbagai tugas lain yang tidak sesuai dengan tugas pokok dan fungsinya.

Hasil penelitian Bahri (Bahri, 2020), menunjukkan bahwa sebagian besar guru BK belum menunjukkan kinerja yang baik (mulai dari perencanaan, pelaksanaan, sampai evaluasi dan tindak lanjut) yang disebabkan karena ketidakmampuan dari guru BK sendiri, dan juga kurang ada dukungan dari kepala sekolah, serta pandangan yang keliru dari guru mata pelajaran, dan wali kelas tentang peran guru BK. Menurut mereka tugas guru BK adalah sebagai penjaga piket, polisi sekolah, dan menangani anak-anak nakal yang tidak disiplin, bolos, dan nakal.

Dari pembahasan tentang faktor-faktor yang mempengaruhi kinerja, dapat dikatakan bahwa pelaksanaan kinerja akan dipengaruhi oleh beberapa faktor baik yang bersumber dari dalam diri pekerja atau karyawan sendiri maupun yang bersumber dari luar atau dari organisasi. Kepala sekolah adalah pemimpin, administrator, dan supervisor, dan pembina di sekolah, yang mempunyai kewajiban untuk membimbing, membina, dan mengawasi kinerja guru BK dalam melaksanakan layanan BK. Kepala sekolah memiliki peran EMASLIM (educator, manajerial, administrator, supervisor, leader, inovator, dan motivator) (De Keizer, H., \& Pringgabayu, 2017). Peran penting itu akan mewarnai kehidupan sekolah dan menentukan keberhasilan pelaksanaan tugas guru di sekolah termasuk guru BK.
Keberhasilan seorang kepala sekolah dalam melaksanakan peran EMASLIM tersebut bergantung pada persepsinya tentang tugas pendidik dan tenaga kependidikan di sekolah yang dipimpinnya. Persepsi merupakan proses mengetahui atau mengenali objek dan kejadian objektif dengan bantuan indera. Artinya bahwa pengenalan terhadap suatu objek atau kejadian objektif tertentu ditentukan oleh kemampuan organisme dalam menggunakan panca inderanya secara baik. Dalam persepsi telah terkandung aspek kognitif yakni pengetahuan, pemahaman dan keyakinan, aspek afektif yang berkaitan dengan perasaan, dan aspek konatif merujuk pada tindakan terkait dengan sesuatu (Hamlyn, 2017). Jadi persepsi dapat diartikan sebagai suatu pengetahuan, pemahaman, keyakinan, perasaan, dan tindakan seseorang untuk merespons terhadap rangsangan tertentu berupa data, keterangan atau informasi yang datang dari luar (Brown, 2019).

Persepsi dipengaruhi oleh pengalaman-pengalaman dan cara berpikir serta keadaan perasaan atau minat tiaptiap orang. Karena itu tidak mengherankan jika seringkali terjadi perbedaan paham yang disebabkan oleh perbedaan persepsi antara dua orang terhadap satu objek. Persepsi tidak sekadar pengenalan atau pemahaman tetapi juga evaluasi bahkan persepsi juga bersifat menarik kesimpulan. Sedangkan faktor-faktor yang mempengaruhi persepsi adalah: kemampuan dan keterbatasan fisik dari alat indera dapat mempengaruhi persepsi untuk sementara waktu ataupun permanen, kondisi lingkungan, pengalaman masa lalu, bagaimana cara individu untuk menginterpretasikan atau bereaksi terhadap suatu stimulus tergantung dari pengalaman masa lalunya, kebutuhan dan keinginan, serta kepercayaan, prasangka, dan nilai. Individu akan lebih memperhatikan dan menerima orang lain yang memiliki kepercayaan dan nilai yang sama dengannya. Sedangkan prasangka dapat menimbulkan bias dalam memersepsikan sesuatu (Imron dkk, 2021).

Dalam penelitian ini, persepsi kepala sekolah terkait dengan kinerja guru BK dapat memberi makna sebagai pengetahuan, pemahaman, keyakinan, perasaan, dan tindakan kepala sekolah berkaitan dengan bagaimana guru BK melaksanakan tugas pokoknya dalam bidang BK, yang meliputi 3 dimensi utama yaitu perencanaan, pelaksanaan, serta evaluasi dan tindak lanjut layanan BK di sekolah.

\section{RUANG LINGKUP}

Penelitian ini dilaksanakan di SMP, SMA, dan SMK di Kota Kupang, dengan fokus pada kinerja guru BK menurut persepsi kepala sekolah sebagai pemimpin, manajer, dan supervisor terhadap semua kegiatan yang dilaksanakan oleh semua warga sekolah, khususnya dalam hal ini guru BK. Kinerja guru BK meliputi kegiatan perencanaan, pelaksanaan, serta evaluasi dan tindak lanjut. 


\section{BAHAN DAN METODE}

Penelitian ini dilaksanakan di SMP, SMA, dan SMK di Kota Kupang selama 3 minggu pada bulan Agustus 2021, dengan desain sebagai berikut :

\subsection{Desain Penelitian, Populasi dan Sampel}

Penelitian ini menggunakan pendekatan kuantitatif dengan jenis penelitian survey, yang berupaya menggambarkan kondisi di lapangan berkaitan dengan kinerja guru BK sesuai dengan kenyataannya, apa adanya, dan sesuai dengan persepsi kepala sekolah.

Populasi dalam penelitian ini adalah Kepala Sekolah SMP, SMA, dan SMK di Kota Kupang yang berhasil diidentifikasi sebanyak 79 orang yang sekolahnya memiliki guru BK. Ditetapkannya kepala sekolah sebagai sampel penelitian karena perannya yang menentukan keberhasilan pelaksanaan tugas guru BK di sekolah. Teknik sampling nya adalah simple random sampling dan sampel diambil sebanyak 65 orang menggunakan tabel penentuan jumlah sampel yang dikembangkan oleh Isaac dan Michael pada taraf kesalahan 5\% (Sugiyono, 2013).

Tabel 1 menunjukkan perincian jumlah populasi kepala sekolah di Kota Kupang yang sekolahnya memiliki guru BK.

Tabel 1. Rincian Anggota Populasi Kepala Sekolah SMP, SMA, dan SMK

\begin{tabular}{|c|c|c|c|}
\hline Sekolah & Negeri & Swasta & Jumlah \\
\hline SMP & 20 & 25 & 45 \\
\hline SMA & 12 & 12 & 24 \\
\hline SMK & 7 & 3 & 10 \\
\hline Jumlah & 39 & 40 & 79 \\
\hline
\end{tabular}

Sedangkan tabel 2 adalah rincian jumlah sampel kepala sekolah.

Tabel 2. Jumlah Anggota Sampel

\begin{tabular}{|c|c|c|c|}
\hline Sekolah & Negeri & Swasta & Jumlah \\
\hline SMP & 14 & 17 & 31 \\
\hline SMA & 12 & 12 & 24 \\
\hline SMK & 7 & 3 & 10 \\
\hline Jumlah & 33 & 32 & 65 \\
\hline
\end{tabular}

\subsection{Metode Pengumpulan Data dan Analisis Data}

Alat pengumpul data menggunakan kuesioner dengan skala Likert untuk mengukur kinerja guru BK dan dilengkapi dengan pertanyaan terbuka. Kuesioner dikembangkan berdasarkan rumusan definisi operasional kinerja guru BK. Kinerja guru BK merujuk pada tampilan perilaku kerja seorang guru BK yang meliputi perencanaan/pengembangan program, pelaksanaan layanan - layanan BK, serta evaluasi dan tindak lanjut. Kuesioner terdiri dari 42 butir dengan rincian 13 untuk aspek perencanaan/pengembangan program, 17 aspek pelaksanaan layanan, dan 12 aspek evaluasi dan tindak lanjut, serta alternatif jawabannya menggunakan skala likert yang dimodifikasi dari Sugiyono.
Kriteria yang digunakan untuk pedoman skoring terdiri dari 5 gradasi seperti terlihat pada tabel 3.

Tabel 3. Alternatif Jawaban dan Pedoman Skoring

\begin{tabular}{|c|c|c|c|}
\hline \multirow{2}{*}{ No } & Skala & \multicolumn{2}{|c|}{ Skor } \\
\cline { 3 - 4 } & & Item + & Item - \\
\hline 1 & Sangat Sesuai & 5 & 1 \\
\hline 2 & Sesuai & 4 & 2 \\
\hline 3 & Netral & 3 & 3 \\
\hline 4 & Tidak Sesuai & 2 & 4 \\
\hline 5 & Sangat Tidak Sesuai & 1 & 5 \\
\hline
\end{tabular}

(Sugiyono, 2013)

Kuesioner yang digunakan memiliki validitas mulai dari $0.430-0.810$ yang dihitung menggunakan rumus Product Moment dari Pearson. Sedangkan hasil uji reliabilitas kuesioner, nilai alpha cronbach yang diperoleh 0.872 yang berarti lebih dari 0.6 sehingga alat pengumpul data atau angket tersebut reliabel.

Data yang diperoleh diolah dan dianalisis menggunakan analisis persentase. Adapun alur penelitian dapat dilihat pada gambar 1. 
(C) 2021, The Author(s). This is an open access article, free of all copyright, that anyone can freely read, download, copy, distribute, print, search, or link to the full texts or use them for any other lawful purpose. This article is made available under a Creative Commons Attribution 4.0 International License, which permits unrestricted use, distribution, and reproduction in any medium, provided the original work is properly cited. SEBATIK is a journal of the STMIK Widya Cipta Dharma

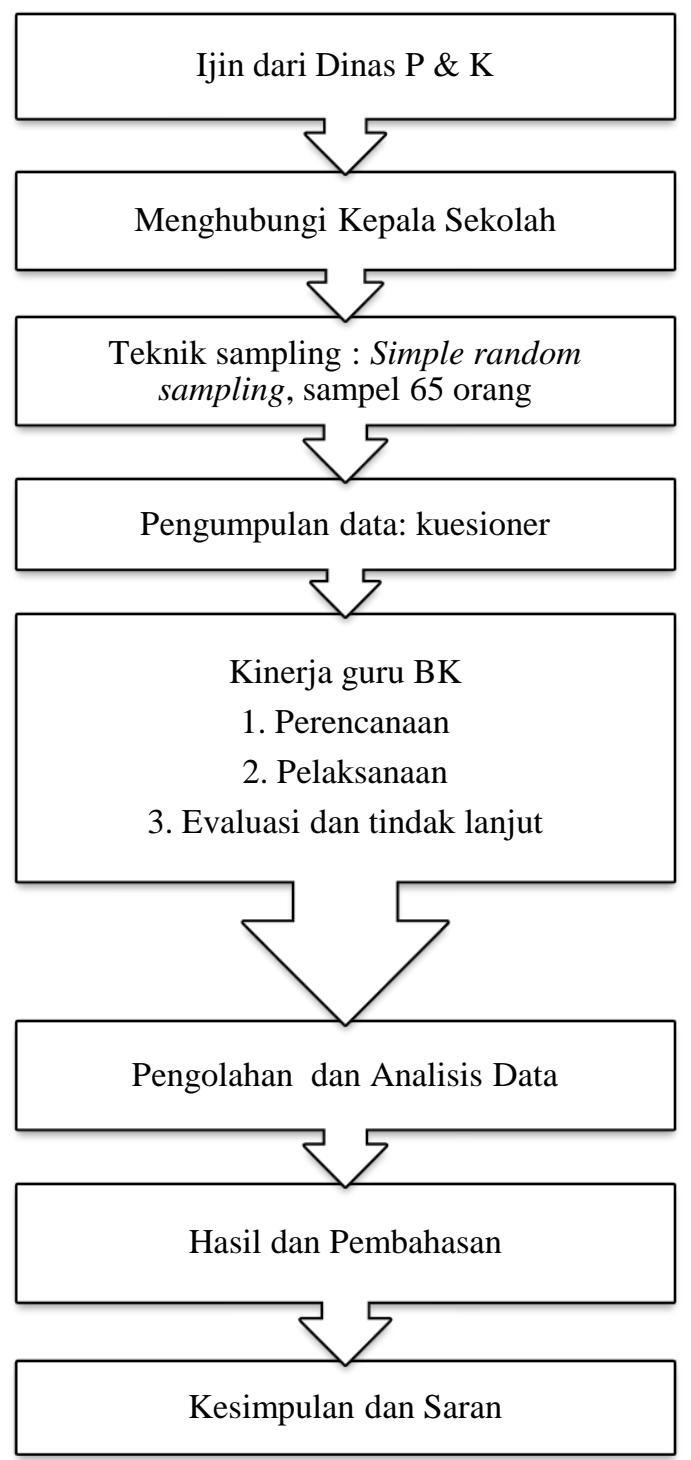

Gambar 1. Skema Alur Penelitian

\section{PEMBAHASAN}

Data penelitian ini diolah dan dianalisis menggunakan analisis persentase. Hasil analisis data disajikan dalam bentuk tabel yang dilengkapi dengan penjelasan. Setelah data disajikan, dibahas sekaligus merujuk pada hasil penelitian terdahulu. Penyajiannya sebagai berikut :

\subsection{Kinerja Guru BK berdasarkan jawaban kuesioner}

Setelah data diolah, kemudian dibuat pengategorian dan persentase. Tabel 4 menunjukkan bahwa dari 65 kepala sekolah yang diteliti, kinerja guru BK cukup dikemukakan oleh 36 orang (55\%), kurang dan sangat kurang 24 orang (37\%), dan baik serta amat baik 5 orang $(8 \%)$.
Tabel 4. Kinerja Guru BK Secara Umum

\begin{tabular}{|c|c|c|c|}
\hline Interval & Kategori & Frekuensi & $\%$-ase \\
\hline $178-210$ & Sangat Baik & 2 & 3 \\
\hline $144-177$ & Baik & 3 & 5 \\
\hline $110-143$ & Cukup & 36 & 55 \\
\hline $76-109$ & Kurang & 13 & 20 \\
\hline $42-75$ & Sangat Kurang & 11 & 17 \\
\hline \multicolumn{2}{|c|}{ Jumlah } & 65 & $100 \%$ \\
\hline
\end{tabular}

Ini berarti bahwa secara keseluruhan, baik itu perencanaan dan pengembangan program, pelaksanaan kegiatan-kegiatan, serta evaluasi dan tindak lanjut, guru BK menunjukkan kinerja cukup (rata - rata), belum menunjukkan kinerja yang baik.

1. Kinerja Guru BK dalam Perencanaan

Tabel 5 menunjukkan bahwa dari 65 kepala sekolah yang diteliti, yang menyatakan kinerja guru BK dalam perencanaan sangat baik, 3 orang $(5 \%)$; baik, 3 orang (5\%); cukup, 38 orang (58\%); kurang, 11 orang (17\%); dan sangat kurang, 10 orang (15\%)

Tabel 5. Kinerja Guru BK dalam Perencanaan

\begin{tabular}{|c|c|c|c|}
\hline Interval & Kategori & Frekuensi & $\%$-ase \\
\hline $57-67$ & Sangat Baik & 3 & 5 \\
\hline $46-56$ & Baik & 3 & 5 \\
\hline $35-45$ & Cukup & 38 & 58 \\
\hline $24-34$ & Kurang & 11 & 17 \\
\hline $13-23$ & Sangat Kurang & 10 & 15 \\
\hline \multicolumn{2}{|c|}{ Jumlah } & 65 & $100 \%$ \\
\hline
\end{tabular}

Hal tersebut menunjukkan bahwa kinerja guru BK dalam aspek perencanaan/pengembangan program, belum baik. Ini berarti bahwa kinerja guru BK dalam perencanaan program berada pada kategori rata - rata, belum maksimal, dan bahkan cenderung kurang. Perencanaan BK di sekolah merupakan tindakan menetapkan tujuan yang akan dicapai berdasarkan pada identifikasi dan analisis kebutuhan peserta didik dan kebutuhan lingkungan, kegiatan-kegiatan yang akan dilakukan dan bagaimana melakukannya agar tujuan tercapai, siapa pihak-pihak yang terlibat, serta sarana dan prasarana yang dibutuhkan. Perencanaan yang komprehensif dan jelas, memberikan pedoman yang memudahkan guru BK melaksanakan kegiatan dengan lancar, efektif, dan efisien.

2. Kinerja Guru BK dalam Pelaksanaan Program BK

Tabel 6 menunjukkan bahwa dari 65 kepala sekolah yang diteliti, yang menyatakan kinerja guru BK dalam pelaksanaan program atau layanan-layanan BK, sangat baik, 3 orang (5\%); baik, 5 orang (8\%); cukup, 36 orang $(55 \%)$; kurang, 8 orang $(12 \%)$; dan sangat kurang, 6 orang $(9 \%)$. 
Tabel 6. Kinerja Guru BK dalam Pelaksanaan

\begin{tabular}{|c|c|c|c|}
\hline Interval & Kategori & Frekuensi & $\%$-ase \\
\hline $73-85$ & Sangat Baik & 3 & 5 \\
\hline $59-72$ & Baik & 5 & 8 \\
\hline $45-58$ & Cukup & 36 & 55 \\
\hline $31-44$ & Kurang & 9 & 14 \\
\hline $17-30$ & Sangat Kurang & 12 & 18 \\
\hline \multicolumn{2}{|c|}{ Jumlah } & 65 & $100 \%$ \\
\hline
\end{tabular}

Ini berarti bahwa kinerja guru BK berada pada kategori rata - rata, belum maksimal, belum menunjukkan kinerja yang baik, bahkan cenderung kurang. Pelaksanaan merupakan kegiatan mewujudkan rencana yang sudah dibuat pada tahap sebelumnya. Pelaksanaan BK merujuk pada implementasi layananlayanan BK yang telah disusun dalam program harian, mingguan, semesteran, dan tahunan.

3. Kinerja Guru BK dalam Evaluasi dan Tindak Lanjut Program BK

Tabel 7 menunjukkan bahwa dari 65 kepala sekolah yang diteliti, yang menyatakan kinerja guru BK dalam evaluasi dan tindak lanjut sangat baik, 5 orang $(8 \%)$; baik, 5 orang (8\%); cukup, 41 orang (63\%); kurang, 8 orang (12\%); dan sangat kurang, 6 orang (9\%)

Tabel 7. Kinerja Guru BK dalam Evaluasi dan Tindak Lanjut

\begin{tabular}{|c|c|c|c|}
\hline & & \\
\hline Interval & Kategori & Frekuensi & $\%$-ase \\
\hline $52-61$ & Sangat Baik & 5 & 8 \\
\hline $42-51$ & Baik & 5 & 8 \\
\hline $32-41$ & Cukup & 41 & 63 \\
\hline $22-31$ & Kurang & 8 & 12 \\
\hline $12-21$ & Sangat Kurang & 6 & 9 \\
\hline \multicolumn{2}{|r|}{ Jumlah } & 65 & $100 \%$ \\
\hline
\end{tabular}

Ini berarti bahwa kinerja guru BK dalam aspek evaluasi dan tindak lanjut berada pada kategori rata rata dan belum maksimal. Walaupun jika dibandingkan dengan aspek perencanaan dan pelaksanaan, aspek evaluasi dan tindak lanjut menunjukkan jumlah dan persentase yang lebih tinggi, namun kategorinya sama yaitu cukup. Evaluasi merupakan kegiatan untuk memperoleh data tentang efisiensi dan efektivitas program bimbingan yang sudah dilaksanakan. Berdasarkan hasil evaluasi, dirumuskan tindak lanjut yang merujuk pada langkah-langkah perbaikan program. Dengan demikian, kegiatan-kegiatan yang direncanakan dan dilaksanakan pada waktu selanjutnya sesuai dengan hasil evaluasi.

\subsection{Hasil jawaban atas pertanyaan terbuka}

Data yang diperoleh dari pertanyaan terbuka, disimpulkan sebagai berikut:

1. Setiap awal tahun guru BK menyusun program tahunan, semesteran, bulanan, bahkan sampai program mingguan.

2. Hanya sebagian kecil guru BK yang melakukan need assessment, sehingga program yang disusun tidak sesuai dengan perkembangan dan kebutuhan siswa.
3. Pelaksanaan layanan BK di sekolah hanya terpusat pada layanan-layanan tertentu misalnya layanan orientasi dan informasi pada saat masa orientasi sekolah bagi siswa baru.

4. Selain layanan orientasi, guru BK juga berperan pada saat rapat penentuan kenaikan kelas dengan memberi informasi tentang rata-rata nilai siswa.

5. Guru BK berharap ada jam khusus BK padahal di sekolah tidak ada jam BK, dan mereka tidak kreatif menemukan strategi lain untuk dapat melayani siswa.

6. Guru BK sering dibebani dengan tugas - tugas lain misalnya menertibkan siswa yang melanggar aturan, memanggil orang tua yang anaknya bermasalah untuk diberi teguran, mengontrol setiap kelas supaya tidak gaduh, dan hitung nilai siswa. Hal ini disebabkan karena guru BK tidak menjalankan program yang sudah disusun pada awal tahun.

7. Guru BK diharapkan untuk membantu kesulitankesulitan siswa baik yang berkaitan dengan urusan pribadi maupun kesulitan pada setiap bidang studi, sehingga tidak membebani guru bidang studi yang harus menyelesaikan materi agar siswa dapat mencapai KKM setiap bidang studi.

8. Guru BK harus bisa memanfaatkan waktu kapan saja selama masih jam sekolah dan tempat di mana saja di lingkungan sekolah untuk melakukan konseling bagi siswa, sehingga tidak perlu ruangan khusus BK dan fasilitas lainnya.

9. Guru BK harus selalu siap sedia untuk mengisi waktu dengan layanan BK (informasi, bimbingan klasikal, bimbingan kelompok, konseling kelompok) ketika guru bidang studi tidak masuk memberikan pelajaran.

10. Ada 8 sekolah yang mempunyai jam khusus BK $1 \mathrm{x}$ seminggu dengan waktu 1 x 40 menit. Guru BK diharapkan dapat memanfaatkan waktu itu sebaik mungkin untuk memilih dan melaksanakan layanan BK bagi siswa.

Penelitian ini menunjukkan kinerja guru BK, baik secara umum maupun setiap aspeknya dari perencanaan/pengembangan program, pelaksanaan, serta evaluasi dan tindak lanjut, cukup. Dapat dikatakan bahwa menurut pemahaman, keyakinan, pandangan, perasaan, dan tindakan kepala sekolah, kinerja guru BK rata-rata, sedang-sedang saja dan belum maksimal. Hal ini sejalan dengan penelitian yang dilakukan oleh Suryarsi, dkk (Suryarsi, S., Hidayat, D.R., \& Badrujaman, 2019) yang menunjukkan bahwa secara umum kinerja guru BK SMP di Sub Rayon 01 Kota Bekasi menurut, rata-rata cukup. Namun jika dilihat dari aspeknya, maka ada perbedaan yaitu aspek perencanaan baik, pelaksanaan baik, sedangkan untuk aspek evaluasi dan tindak lanjut kurang. Hasil penelitian ini bertentangan dengan penelitian yang dilakukan oleh Adi, dkk (Adi dkk, 2015) yang menemukan bahwa kinerja guru BK se Kabupaten Tabanan termasuk dalam kategori sangat baik. 
Penelitian ini juga menunjukkan bahwa faktor persepsi dari kepala sekolah sebagai pemimpin, manajer, dan supervisor bagi semua kegiatan pendidikan di sekolah termasuk kegiatan BK akan berdampak pada kinerja guru BK. Persepsi yang tepat terhadap tugas Guru BK, akan membuat kepala sekolah memiliki interpretasi yang tepat tentang tugas pokok guru BK, memiliki kepercayaan akan kemampuan guru BK dalam melaksanakan tugasnya, dan pada akhirnya akan memberikan tugas yang sesuai dengan tupoksi seorang guru BK. Hal ini sejalan dengan hasil penelitian dari Lubis, dkk (Lubis, L.S.P., Solehuddin., \& Budiman, 2020) yang menjelaskan bahwa kinerja guru BK di lapangan cukup, dan mereka cenderung tidak menunjukkan kinerja yang sesungguhnya disebabkan karena terbatasnya akses dari segi waktu, jumlah peserta didik, sarana dan prasarana, serta dukungan dari kepala sekolah.

Dalam tahap perencanaan guru BK sudah menyusun silabus, program tahunan, program semester, dan program harian, tetapi hanya sebagian kecil guru BK yang melakukan need assessment sehingga program yang disusun tidak sesuai dengan kebutuhan dan tugas perkembangan siswa. Hal ini bertentangan dengan hasil penelitian Karsono yang menunjukkan bahwa setelah ada supervisi klinis dari pengawas sekolah, kinerja guru BK di kelompok kerja Delanggu - Klaten dalam perencanaan program BK sangat baik (Karsono, 2016).

Untuk tahap pelaksanaan, layanan bimbingan yang dapat dilakukan sangat terbatas pada layanan orientasi dan konsultasi, sedangkan bimbingan klasikal, bimbingan kelompok, penguasaan konten, layanan konseling (individual dan kelompok), layanan penempatan dan penyaluran, pengumpulan data siswa, dan kunjungan rumah jarang dilakukan. Hal ini sejalan dengan penelitian Putranti, dkk (Putranti, D., Fithroni, F., \& Kusumaningtias, 2020) yang menunjukkan bahwa kepala sekolah kurang menjalankan perannya sebagai pemimpin dalam implementasi program bimbingan dan konseling. Jadwal tatap muka dengan peserta didik tidak tersedia, kurang koordinasi antara kepala sekolah dengan guru BK, serta sarana dan prasarana yang kurang memadai, menunjukkan kurangnya pemahaman kepala sekolah terhadap peran guru BK.

Sedangkan evaluasi dilaksanakan pada setiap akhir semester dan terbatas pada layanan-layanan yang dilakukan. Sejalan dengan evaluasi yang terbatas, maka kegiatan tindak lanjut untuk perbaikan program di masa yang akan datang, juga tidak dilakukan. Dengan demikian, tidak ada perubahan yang berarti dalam pelaksanaan bimbingan dan konseling dari waktu ke waktu. Keadaan yang sama berulang dari semester ke semester dan dari tahun ke tahun. Evaluasi yang menyeluruh harus dilakukan pada semua aspek, tidak saja pada guru BK tetapi terhadap semua komponen yang berkaitan. Afdal dalam kajiannya menyimpulkan bahwa keberhasilan pelaksanaan bimbingan dan konseling di sekolah tidak hanya bergantung pada guru
BK, tetapi juga pada personil sekolah lainnya seperti guru, peserta didik, dan kepala sekolah, serta lingkungan di luar sekolah dalam hal ini orang tua, masyarakat, dan pihak lain yang terkait. Melalui kolaborasi antar semua pihak tersebut, semua kegiatan pendidikan di sekolah termasuk bimbingan dan konseling akan membantu optimalisasi perkembangan peserta didik (Afdal, 2015).

Hampir $71 \%$ (46) sekolah tidak ada jam khusus bimbingan sehingga guru BK harus mencari waktu sendiri untuk dapat melaksanakan layanan-layanan BK. Hal ini sejalan dengan hasil penelitian Saputri, dkk, yang menunjukkan bahwa pelaksanaan layanan BK di sekolah belum berjalan optimal dan profesional disebabkan karena tidak ada jam masuk kelas dan belum tersedianya sarana, prasarana yang menunjang pelaksanaan layanan BK di antaranya tidak tersedia ruangan BK dan kebutuhan lain yang dianggap perlu dalam pelaksanaan layanan BK yang sesuai dengan Pedoman Operasional Penyelenggaraan BK (POP BK). Ada juga sekolah yang menyediakan jam khusus BK namun sangat terbatas, sehingga menuntut guru BK untuk selalu siap sedia dan kreatif memanfaatkan waktu yang tersedia sehingga semua layanan BK yang diprogramkan dapat terlaksana (Saputri, S.M., Prayitno., \& Jaya, 2018).

Selain itu, dari jawaban terhadap pertanyaan terbuka yang diberikan terungkap bahwa di sekolah tidak tersedia jam khusus BK, yang tersedia pun waktunya sangat terbatas ( $1 \mathrm{x}$ seminggu dan $\left.1 \mathrm{x} 40^{\prime}\right)$. Ini adalah salah satu kesulitan yang dialami guru BK dalam melaksanakan kegiatan BK secara optimal. Keberhasilan guru BK dalam melaksanakan tugasnya dapat dilihat dari

1. Guru BK menjalankan tugas pokok dan fungsinya dalam pelayanan BK di sekolah.

2. Ada kegiatan tatap muka di dalam kelas selama 2 jam pembelajaran per minggu setiap kelasnya, untuk melakukan pembelajaran dalam bidang pelayanan BK.

3. Ada siswa asuh dengan rasio $1: 150$.

4. Ada sarana, prasarana, dan pembiayaan dalam menunjang pelaksanaan pelayanan BK

Permendikbud Nomor 111 tahun 2014 menjelaskan bahwa kinerja guru BK diukur dari kompetensi yang terdiri dari 2 komponen yaitu kompetensi akademik yang berkaitan dengan pemahaman terhadap konseling dengan segala karakteristiknya serta penguasaan khasanah teoretis bimbingan dan konseling, dan kompetensi profesional yang berkaitan dengan pengembangan program BK, pelaksanaan layanan BK, serta evaluasi dan tindak lanjutnya (Kementerian Pendidikan Dan Kebudayaan, 2014). Dengan demikian, guru BK sebagai salah satu komponen pelayanan siswa berperan untuk support perkembangan aspek pribadi, sosial, karier, dan akademik siswa.

Kinerja guru BK adalah gambaran hasil kerja yang dilakukan oleh guru BK terkait dengan tugas apa yang diembannya dan merupakan tanggung jawabnya; serta merupakan salah satu faktor yang menjadi tolok ukur keberhasilan pelaksanaan BK di Sekolah. Kinerja 
sebagai hasil kerja guru BK, tergambar dalam cara merencanakan, melaksanakan, menilai serta melakukan tindak lanjut pelayanan BK yang intensitasnya dilandasi oleh etos kerja serta disiplin profesional guru BK dalam proses pelayanan $\mathrm{BK}$.

Selain ditentukan oleh etos kerja dan disiplin profesional guru BK, kinerja seorang guru BK dipengaruhi juga oleh faktor - faktor eksternal seperti suasana/iklim organisasi sekolah, persepsi kepala sekolah (persepsi, pemahaman, kepemimpinan, dan pembinaan), persepsi guru bidang studi, dan persepsi siswa sebagai sasaran layanan BK. Kepala sekolah sebagai pemimpin bertanggung jawab atas semua kegiatan penyelenggaraan pendidikan, administrasi, pembinaan tenaga kependidikan lainnya, dan pendayagunaan serta pemeliharaan sarana dan prasarana. Guru sebagai rekan sejawat merupakan kolega yang bekerja sama untuk kemajuan perkembangan siswa (Khansa, 2015). Sedangkan siswa adalah pihak yang mengambil manfaat dari kegiatan yang dilakukan oleh guru BK (Busmayaril, 2016).

Hasil penelitian ini juga menunjukkan bahwa kepala sekolah sebagai pengguna lulusan menaruh harapan yang besar terhadap kinerja guru BK mulai dari tahap perencanaan, tahap pelaksanaan, dan tahap evaluasi dan tindak lanjut. Harapan ini didukung oleh jawaban terhadap pertanyaan yang diberikan, yaitu :

1. Guru BK sering dibebani dengan tugas - tugas lain misalnya menertibkan siswa yang melanggar aturan, memanggil orang tua yang anaknya bermasalah untuk diberi teguran, mengontrol setiap kelas supaya tidak gaduh, dan merekap nilai siswa. Hal ini disebabkan karena guru BK tidak menjalankan program yang sudah disusun pada awal tahun.

2. Guru BK diharapkan untuk membantu kesulitankesulitan siswa baik yang berkaitan dengan urusan pribadi maupun kesulitan pada setiap bidang studi, sehingga tidak membebani guru bidang studi yang harus menyelesaikan materi agar siswa dapat mencapai KKM setiap bidang studi.

3. Guru BK harus bisa memanfaatkan waktu kapan saja selama masih jam sekolah dan tempat di mana saja di lingkungan sekolah untuk melakukan konseling bagi siswa, sehingga tidak perlu ruangan khusus BK dan fasilitas lainnya.

4. Guru BK harus selalu siap sedia untuk mengisi waktu dengan layanan BK (informasi, bimbingan klasikal, bimbingan kelompok, konseling kelompok) ketika guru bidang studi tidak masuk memberikan pelajaran. Selain kepala sekolah, personil sekolah lainnya yakni guru juga mempunyai persepsi tentang kinerja guru BK, yang juga mempengaruhi pelaksanaan tugas mereka. Seperti yang ditemukan oleh Irawan \& Meylani dalam penelitian mereka bahwa kinerja guru BK dalam melaksanakan layanan bimbingan konseling di sekolah kurang baik (Irawan, S., \& Meylani, 2021).

Hal - hal tersebut menunjukkan bahwa kinerja seorang guru BK dipengaruhi juga oleh pemahaman dan harapan yang tidak realistis dari kepala sekolah. Kinerja guru pembimbing dipengaruhi oleh kompetensi yang dimilikinya serta faktor lingkungan seperti perilaku, sikap, tindakan rekan kerja, perlakuan pimpinan, harapan dan tuntutan pimpinan yang tidak realistis dan terlalu tinggi, fasilitas kerja, serta iklim organisasi (Indrasari, 2017).

Berkaitan dengan hal tersebut, kinerja seseorang ditentukan oleh kejelasan tugas (pekerjaan yang menjadi tanggung jawab), kejelasan waktu untuk menyelesaikan tugas, dan kejelasan hasil yang diharapkan. Hal ini berkaitan erat dengan kompetensi (Astiti, P, 2018). Selain itu, faktor organisasi, seperti gaya kepemimpinan, harapan dan tuntutan dalam organisasi sangat berperan dalam mempengaruhi kinerja karyawan. Harapan dan tuntutan yang terlampau tinggi bisa saja disebabkan karena personil sekolah termasuk pimpinan dan guru guru yang belum memahami apa yang seharusnya dilakukan bidang BK di sekolah. Hal ini sejalan dengan hasil penelitian Babtista dkk (Babtista, O., Ernawati., 2020) yang mengungkapkan bahwa kinerja guru BK belum memuaskan dan belum seharusnya. Masih terdapat guru BK yang kurang baik dalam melaksanakan tugasnya karena masih lemah dalam

1) memahami konsep - konsep bimbingan secara komprehensif,

2) menyusun program $B K$,

3) mengimplementasikan teknik - teknik BK,

4) kemampuan berkolaborasi dengan pimpinan sekolah dan guru - guru mata pelajaran,

5) mengelola BK,

6) mengevaluasi program (proses dan hasil) bimbingan dan konseling,

7) melakukan tindak lanjut (follow up) hasil evaluasi untuk perbaikan atau pengembangan program,

serta pimpinan sekolah yang belum memahami konsep dan keberadaan bimbingan dan konseling di sekolah, sehingga harapan dan tuntutan mereka tidak sesuai dengan hakikat bimbingan dan konseling itu sendiri.

Berkenaan dengan kinerja guru BK, dimensi kinerja adalah hal-hal yang berkaitan dengan proses dan hasil pekerjaan yang dijalankan oleh guru BK. Indikator kinerja guru BK disesuaikan dengan standar kualifikasi akademik dan kompetensi konselor yaitu kompetensi pedagogik, kompetensi kepribadian, kompetensi sosial, dan kompetensi profesional. Hadi dalam penelitiannya menemukan bahwa kompetensi pedagogik dan kompetensi profesional berpengaruh signifikan terhadap kinerja guru BK (Hadi, 2018).

Kompetensi - kompetensi guru BK tersebut dirumuskan dalam 17 sub kompetensi yaitu :

1. Kompetensi pedagogik :

1) Menguasai teori dan praksis pendidikan

2) Mengaplikasikan perkembangan fisiologis dan psikologis serta perilaku konseling

3) Menguasai esensi layanan BK dalam jalur, jenis, dan jenjang satuan pendidikan

2. Kompetensi kepribadian 
1) Beriman dan bertakwa kepada Tuhan yang Maha Esa

2) Menghargai dan menjunjung tinggi nilai - nilai kemanusiaan individu dan kebebasan memilih

3) Menunjukkan integritas dan stabilitas kepribadian yang kuat

4) Menampilkan kinerja berkualitas tinggi

3. Kompetensi Sosial

1) Mengimplementasikan kolaborasi internal di tempat kerja

2) Berperan dalam organisasi dan kegiatan profesi BK

3) Mengimplementasikan kolaborasi antar profesi

4. Kompetensi Profesional

1) Menguasai konsep dan praksis assessment untuk memahami kondisi, kebutuhan, dan masalah konseling

2) Menguasai kerangka teoretis dan praksis BK

3) Merancang program $\mathrm{BK}$

4) Mengimplementasikan program BK yang komprehensif

5) Menilai proses dan hasil kegiatan $\mathrm{BK}$

6) Memiliki kesadaran dan komitmen terhadap etika profesional

7) Menguasai konsep dan praksis penelitian dalam BK (Kementerian Pendidikan dan Kebudayaan, 2014).

Ke 17 sub kompetensi tersebut secara operasional diterapkan dalam 3 tahapan kegiatan yaitu tahap perencanaan, tahap pelaksanaan bimbingan, dan tahap evaluasi (proses dan hasil) dan tindak lanjut.

Kinerja seseorang dapat diketahui jika dilakukan penilaian agar dapat dilakukan perbaikan dan peningkatan kinerja itu sendiri di masa yang akan datang. Penilaian kinerja guru BK, mengacu pada tahapan penyelenggaraan BK yakni tahap perencanaan atau rencana pelaksanaan layanan, pelaksanaan program BK serta evaluasi dan tindak lanjut layanan BK. Dalam tahap perencanaan, program $\mathrm{BK}$ harus berdasarkan pada assessment kebutuhan peserta didik dan assessment kebutuhan lingkungan; pada tataran pelaksanaan, idealnya kegiatan BK di sekolah mencakup berbagai layanan dan kegiatan pendukung; dan harus dilanjutkan dengan kegiatan evaluasi dan tindak lanjut agar dapat diketahui sejauh mana kegiatan yang dilaksanakan membawa dampak bagi perkembangan peserta didik sehingga dapat dirumuskan tindak lanjut yang tepat (Kementerian Pendidikan dan Kebudayaan, 2013). Kinerja guru BK dipengaruhi oleh faktor internal (dalam diri sendiri) dan juga faktor eksternal (dari luar diri). Oleh sebab itu, penilaian kinerja guru BK harus dilakukan menyeluruh terhadap semua faktor. Dengan demikian, evaluasi kinerja guru BK harus dilakukan dengan melibatkan guru BK sendiri melalui selfevaluation dan peer evaluation yang dilakukan oleh teman guru dan kepala sekolah (Barida, M., \& Sutarno, 2018).
Hasil penelitian ini membawa implikasi terhadap upaya peningkatan profesionalitas guru bimbingan dan konseling. Beberapa program yang dapat dilakukan untuk meningkatkan kemampuan profesional guru BK yakni:

1. Individual Guided Staff Development, yakni pengembangan guru yang dipandu secara individual, di mana setiap guru BK diarahkan untuk meningkatkan profesionalitas nya sesuai dengan kondisi dan keinginan masing - masing dipandu oleh guru yang berpengalaman atau kepala sekolah yang sungguh memahami bidang ini.

2. Observation/Assessment, yakni melakukan pengamatan atau penilaian terhadap kinerja guru BK untuk selanjutnya dilakukan pembinaan atas dasar kekurangan yang ditemui pada saat pengamatan dan penilaian.

3. Involvement in a Development/Improvement Process, yakni pengembangan melalui keterlibatan dalam suatu proses peningkatan, misalnya mengikutsertakan guru BK dalam kegiatan lokakarya dan magang, agar ia memperoleh pengetahuan dan pengalaman untuk pengembangan dirinya. Melalui kegiatan ini mereka memperoleh kesempatan berinteraksi dan berdiskusi dengan kolega sesama profesi.

4. Training, yakni pengembangan profesionalitas melalui latihan atau diklat tentang BK yang dapat dilakukan oleh organisasi profesi ABKIN, Prodi Bimbingan dan Konseling, Lembaga Penjaminan Mutu Pendidikan, dan Pusat Pengembangan Guru Bimbingan dan Konseling.

5. Inquiry, yakni pengembangan melalui pemeriksaan/penilaian terhadap kinerja guru BK melalui pemeriksaan terhadap dokumen program, laporan pelaksanaan pemberian layanan BK dalam kurun waktu tertentu. Berdasarkan pemeriksaan terhadap dokumen tersebut, selanjutnya dilakukan pengembangan pada bagian mana yang dipandang ada kekurangan atau kelemahan

(Wibowo, 2019).

Barida dan Muarifah dalam penelitiannya mengungkapkan bahwa profesionalitas seorang guru BK hanya dapat tercapai jika mereka aktif belajar dan mengembangkan keterampilan melalui rapat keilmuan, seminar, pelatihan, pendidikan profesi, atau kegiatan pengembangan keilmuan lainnya (Barida, M., \& Muarifah, 2019).

\section{KESIMPULAN}

Hasil dari penelitian ini adalah kinerja guru bimbingan konseling, baik secara umum maupun dalam aspek perencanaan program, pelaksanaan layanan, maupun evaluasi dan tindak lanjut menurut pemahaman, pengalaman, keyakinan, penilaian, perasaan, dan tindakan kepala sekolah termasuk dalam kategori cukup.

Ada hambatan yang dialami oleh guru BK dalam menjalankan tugas pokok dan fungsinya, yaitu tidak ada alokasi jam khusus BK, ruang khusus BK dan sarana 
prasarana penunjangnya tidak tersedia, serta sering dibebani dengan tugas-tugas lain di luar tugas pokok dan fungsinya.

\section{SARAN}

Penelitian selanjutnya dapat menganalisis kinerja guru BK secara lebih komprehensif dengan melibatkan variabel yang lebih luas, baik dari pribadi guru BK sendiri, kepala sekolah, siswa, dan pengawas, serta sarana dan prasarana penunjang.

\section{DAFTAR PUSTAKA}

Adi, NI.M .A., Yudana, I. M., \& Sunu, I. G. K. 2015. Kontribusi Perilaku Kepemimpinan Kepala Sekolah, Iklim Kerja, dan Etos Kerja Terhadap Kinerja Guru Bimbingan Konseling Pada SMA Se Kabupaten Tabanan. e-Journal Program Pascasarjana Universitas Pendidikan Ganesha, 6(1), 1-8.

Afdal. 2015. Kolaboratif: Kerangka Kerja Konselor Masa Depan. Jurnal Konseling dan Pendidikan, 3, $1-7$.

Astiti, P, dkk. 2018. Konstruksi Identitas Guru Bimbingan dan Konseling sebagai Komunikator Pendidikan. Jurnal Kajian Komunikasi, 06(1), 1-9.

Babtista, O., Ernawati., \& W. 2020. Persepsi Mahasiswa Bimbingan dan Konseling Terhadap Kinerja Guru Bimbingan dan Konseling. Jurnal Selaras, 3(2), 111-128.

Bahri, S. 2020. Studi Evaluasi Kinerja Guru Bimbingan dan Konseling Di Sekolah. Jurnal Pencerahan, 14(1), 1-23.

Barida, M., \& Muarifah, A. 2019. Perbedaan Kinerja Guru Bimbingan dan Konseling dalam Menyelenggarakan Konseling Individual Ditinjau dari Latar Belakang Pendidikan dan Pengalaman Bekerja. Jurnal Kajian Bimbingan dan Konseling, 4(1), $22-29$. https://doi.org/10.17977/um001v4i12019p022

Barida, M., \& Sutarno, S. 2018. Studi Komparasi Kinerja Konselor dalam Layanan Konseling Individual Berdasarkan Self Evaluation dan Peer Evaluation. Jurnal Kajian Bimbingan dan Konseling, 3(1), 3340.

Brown, C. H. 2019. Perceptions of School Counselors Surviving a School Shooting. Professional School Counseling, 22(1), 1-13. https://doi.org/10.1177/2156759X19853250

Busmayaril, H. 2016. Persepsi Peserta Didik terhadap Pelaksanaan Bimbingan dan Konseling di Sekolah Menengah Atas Negeri 1 Karya Penggawa Kabupaten Pesisir Barat. Konseli: Jurnal Bimbingan dan Konseling, 03(1), 11-18.

De Keizer, H., \& Pringgabayu, D. 2017. Pengaruh Kepemimpinan Kepala Sekolah, Motivasi, dan Budaya Sekolah, Terhadap Kinerja Guru di SMK ICB Cinta Niaga Kota Bandung. Manajemen Bisnis dan Inovasi, 4(1), 14-25.
Hadi, S. 2018. Pengaruh Kompetensi Pedagogik dan Kompetensi Profesional Terhadap Kinerja Guru Bimbingan dan Konseling Di SDLB Kota Bandung. Jurnal Ilmu Politik dan Komunikasi, $\operatorname{VIII}(1)$

Hamlyn, D. 2017. The Psychology of Perseption. Routledge \& Kegan Paul Ltd.

Hapsyah, D.R., \& Herdi, H. 2019. Factors Affecting the Problem of Guidance and Counseling Service Programs in High Schools. KONSELI: Jurnal Bimbingan dan Konseling, 06(2), 99-108.

Imron, M., Naqiyah, N., \& Hastuti, R. 2021. Kinerja Guru Bimbingan dan Konseling SMA Kota Surabaya dan Faktor-faktor yang Mempengaruhinya. Jurnal Bimbingan Konseling Indonesia, 6(111).

Indrasari, M. 2017. Kepuasan Kerja dan Kinerja Karyawan Tinjauan dari Dimensi Iklim Organisasi, Kreativitas Individu, dan Karakteristik Pekerjaan. Indomedia Pustaka.

Irawan, S., \& Meylani, H. 2021. Persepsi Guru Terhadap Layanan Bimbingan dan Konseling. Satya Widya, XXXVI(2), 88-96.

Karsono. 2016. Kinerja Guru Bimbingan Konseling Dalam Penyusunan Rencana Program Layanan Melalui Pendampingan Supervisi Klinis. Jurnal Manajemen Pendidikan, 11, 123-132.

Kemensesneg. 2017. Peraturan Pemerintah Republik Indonesia Nomor 19 Tahun 2017 tentang Guru.

Kementerian Pendidikan dan Kebudayaan. 2013. Permendikbud Nomor 81A Tahun 2013 tentang Implementasi Kurikulum.

Kementerian Pendidikan dan Kebudayaan. 2014. Peraturan Mendikbud No.111 Tahun 2014 tentang Bimbingan dan Konseling pada Pendidikan Dasar dan Pendidikan Menengah.

Khansa, R. (2015). Teachers 'Perceptions toward School Counselors in Selected Private Schools in Lebanon. Procedia - Social and Behavioral Sciences, 185, 381-387. https://doi.org/10.1016/j.sbspro.2015.03.411

Lubis, L.S.P., Solehuddin., \& Budiman, N. (2020). Kinerja Guru Bimbingan dan Konseling Berdasarkan Latar Belakang Masa Kerja. Hadhârah, 12, 49-66.

Nagul, W., Yusuf, A.M., \& S. 2013. Persepsi Tentang Tugas dan Motivasi Kerja Serta Pengaruhnya terhadap Kinerja Guru BK SMPN se-Kota Kupang. Jurnal Konseling dan Pendidikan, 1(1978), 1-8.

Putranti, D., Fithroni, F., \& Kusumaningtias, D. 2020. Peran Kepala Sekolah Dalam Implementasi Program Bimbingan. Jurnal Prakarsa Paedagogia, $3(2)$.

Ramadani, D., \& H. 2021. Studi Kepustakaan Mengenai Kinerja Guru Bimbingan dan Konseling Dalam Perencanaan Program Bimbingan dan Konseling di Sekolah. Jurnal Edukasi, Jurnal Bimbingan 
Konseling, Vol. 7(1), 42-52.

Saputri, S.M., Prayitno., \& Jaya, Y. 2018. Kinerja Guru Bimbingan dan Konseling Serta Pembinaannya. Enlighten: Jurnal Bimbingan Konseling Islam, $1(1), 1-20$.

Siregar, Y. 2018. Pengaruh gaya kepemimpinan kepala sekolah terhadap kinerja guru bimbingan dan konseling di SMA negeri Jakarta Timur. Teraputik, Jurnal Bimbingan dan Konseling, 1(3), 232-238. https://doi.org/10.30998/teraputik.32160

Solikin. 2012. Persepsi Kepala Sekolah , Guru Bidang Studi, dan Siswa Terhadap Pelaksanaan Layanan Bimbingan dan Konseling. Jurnal Ilmiah Pendidikan Bimbingan dan Konseling, 87-98.

Sudibyo, H. 2019. Kinerja Guru BK dalam Perencanaan
Program Bimbingan dan Konseling Komprehensif. JCOSE Jurnal Bimbingan dan Konseling, 1(2), $36-40$.

Sugiyono. 2013. Metode Penelitian Kuantitatif, Kualitatif Dan $R \& D$. Alfabeta.

Supardi. 2016. Kinerja Guru. PT Rajagrafindo Persada. Suryarsi, S., Hidayat, D.R., \& Badrujaman, A. 2019. Kinerja Guru Bimbingan dan Konseling SMP Di Sub Rayon 01 Kota Bekasi. Insight: Jurnal Bimbingan dan Konseling, 8(1), 51-64.

Wibowo, M. E. 2018. Profesi Konseling Abad 21. UNNES Press.

Wibowo, M. E. 2019. Konselor Profesional Abad 21. UNNES Press. 